\title{
Resistance to Brown Stem Rot in Soybean Germ Plasm with Resistance to the Soybean Cyst Nematode
}

\author{
T. J. Hughes, Former Graduate Research Assistant, and N. C. Kurtzweil, Department of Plant Pathology, University \\ of Wisconsin-Madison, Madison 53706; B. W. Diers, Department of Crop Sciences, University of Illinois at Urbana- \\ Champaign, Urbana 61801; and C. R. Grau, Department of Plant Pathology, University of Wisconsin-Madison
}

\begin{abstract}
Hughes, T. J., Kurtzweil, N. C., Diers, B. W., and Grau, C. R. 2004. Resistance to brown stem rot in soybean germ plasm with resistance to the soybean cyst nematode. Plant Dis. 88:761-768.

The soybean cyst nematode (SCN) and Phialophora gregata f. sp. sojae, the causal agent of brown stem rot (BSR), are two pathogens of soybean commonly found in the same field throughout the north-central United States. Field experiments designed to study the role of SCNresistant germ plasm in soybean production have led to data suggesting that some sources of SCN resistance also may provide resistance to BSR. Soybean germ plasm with resistance to SCN was evaluated in greenhouse and field environments for resistance to BSR development based on the percentage of host tissue symptomatic of BSR. Comparison of SCN-resistant cultivars and plant introductions (PI) to standard BSR-resistant and -susceptible checks were conducted in two greenhouse experiments using a root-dip inoculation with a single isolate of $P$. gregata. For both greenhouse experiments, PI 209332 was the only source of SCN resistance with resistance to BSR similar to standard BSR-resistant checks. Nine other sources of SCN resistance, including PI 88788 and Peking, expressed BSR symptom severity similar to BSRsusceptible checks. Cultivars derived from most SCN-resistant sources, including PI 209332, also were susceptible to BSR development, while four of the five cultivars derived from PI 88788 were highly resistant to BSR development. SCN-resistant cultivars derived from PI 88788, Peking, and PI 209332 were planted along with standard BSR-resistant and -susceptible checks at two field locations naturally infested with $P$. gregata and SCN or $P$. gregata alone. As in greenhouse experiments, four of the five cultivars derived from PI 88788 expressed resistance to BSR development equal to or better than standard BSR-resistant checks at both locations. In contrast, cultivars derived from PI 209332 and Peking expressed varying levels of disease development depending on field environment. Yields observed for PI 88788-derived cultivars were higher than BSR-resistant checks regardless of the presence of SCN. Data from both greenhouse and field experiments suggest that cvs. Williams and Williams 82 may contain a gene or genes for BSR resistance that require one or more modifier genes, possibly located in the genome of PI 88788 , for complete expression.
\end{abstract}

The disease brown stem rot (BSR), caused by the fungus Phialophora gregata (Allington \& D. W. Chamberlain) W. Gams f. sp. sojae Kobayashi, Yamamoto, Negishi et Ogoshi, is an economically significant disease of soybean (Glycine $\max$ (L.) Merr) present throughout the north-central United States $(39,40)$. Symptoms of BSR include a progressive browning of the vascular and pith tissues of the root and stem, which may be accompanied by an interveinal chlorosis and necrosis of the foliage leading to wilting and defoliation $(1,12)$. Though internal symptoms are

Corresponding author: T. J. Hughes

E-mail: thughes@pars.ars.usda.gov

This research was funded by the University of Wisconsin-Madison, College of Agriculture and Life Sciences (CALS), Hatch project number 4244 and the Wisconsin Soybean Marketing Board.

Accepted for publication 24 March 2004.

Publication no. D-2004-0517-02R

(C) 2004 The American Phytopathological Society most prevalent, the development of foliar symptoms has been strongly correlated to yield loss and is an effective plant phenotype for differentiating resistant and susceptible soybean genotypes $(30,31)$. When both foliar and internal symptoms are produced, yield losses up to $30 \%$ are common $(11,13,23)$, while yield losses up to $8 \%$ are reported when only the internal stem symptom develops (23).

Currently, the most effective method for controlling BSR is through the use of soybean genotypes resistant to disease development $(5,12,24,35)$. Resistance to BSR is inherited as a quantitative trait and defined as the lack of, or minimal level of, disease symptom expression when compared with the advanced level of symptom development expressed by a standard susceptible soybean genotype (30). Three loci located within the same region on soybean linkage group $\mathrm{J}(7,20)$ and designated $R b s \quad 1$ (14), $R b s 2$ (14), and Rbs 3 (37), have been identified which confer resistance to BSR development. Unfortunately, neither $R b s$, $R b s$ 2, nor $R b s 3$ confer complete resistance, defined as a lack of symptom devel- opment, and the efficacy of both cultivars and breeding lines containing one or more of these genes varies depending on environmental conditions, density of the pathogen population, and pathogen genotype $(6,26,32,36,38)$.

Cultivars with resistance to the soybean cyst nematode (SCN; Heterodera glycines Ichinohe) are derived from a relatively few sources, including plant introduction (PI) 88788, PI 209332, and Peking, with the majority obtaining their resistance from PI 88788 and Peking $(10,41)$. Previous experiments, designed to illustrate the advantage of planting an SCN-resistant cultivar in the presence of SCN (21) or to provide cultivar performance data (both agronomic and disease) across a variety of environments $(19,27)$, have indicated that soybean germ plasm with resistance to $\mathrm{SCN}$ derived from PI 88788 may be a potential source of resistance to BSR (27). Studies $(19,21,27)$ conducted in fields naturally infested with both SCN and $P$. gregata showed that the soybean $\mathrm{cv}$. Bell, derived from PI 88788, expressed BSR foliar symptom severity similar to BSR 101, a cultivar with resistance to BSR ( $R b s$ 1 and $R b s$ 3). Conversely, soybean cv. Newton, derived from Peking, expressed symptom severity similar to cv. Sturdy, a standard BSR-susceptible check $(19,27)$. Willmot et al. (38) further observed resistance to BSR in cv. Fayette, also derived from PI 88788, across two different environments.

In a preliminary greenhouse study, Kurtzweil et al. (18) screened cultivars derived from five sources of SCN resistance (PI 88788, Peking, PI 209332, Cloud, and PI 89772) against $P$. gregata and observed that several cultivars with SCN resistance derived from PI 88788 expressed low BSR symptom severity. Furthermore, a breeding line, LN89-5717, derived from SCN-resistant PI 89772 also expressed low BSR symptom development. In contrast, cultivars derived from Peking, Cloud, and PI 209332 expressed a high level of BSR symptom severity.

With a need to identify new sources of resistance to BSR that remain stable across a variety of environments and differing pathogen populations, and the low levels of BSR symptom development observed in SCN-resistant germ plasm, this study was conducted to (i) evaluate the reaction of PI 88788 to $P$. gregata as a possible source of BSR resistance observed in PI 88788 de- 
rived cultivars, (ii) compare multiple sources of SCN resistance for reaction to BSR development, and (iii) evaluate SCNresistant genotypes for reaction to BSR development across multiple environments.

\section{MATERIALS AND METHODS}

Greenhouse experiments. Ten PIs representing different sources of SCN resistance and 12 cultivars with resistance to SCN derived from six of these sources were selected based on use in breeding programs, preliminary experimental data, and parentage. Both SCN- and BSR-resistant and -susceptible soybean genotypes were included as standardized checks (Table 1). Experiments were conducted in greenhouses located in Madison, WI from January to May 2000. Greenhouses were programmed with 14-h photoperiods supplemented by high-pressure sodium lamps. Average daytime temperatures were $23^{\circ} \mathrm{C}$ for experiment 1 and $27^{\circ} \mathrm{C}$ for experiment 2.

Based on the high correlation between resistance to BSR in the field and the development of foliar symptoms in greenhouse assays $(30,31)$, a single isolate of $P$. gregata, which produces both foliar and internal symptoms, was selected. Stock cultures of genotype A (9) isolate H96-5 were maintained on $P$. gregata-selective media (25) at $16^{\circ} \mathrm{C}$. Working cultures were maintained on potato dextrose agar (100 g of peeled, sliced potato, $5 \mathrm{~g}$ of dextrose, 6 $\mathrm{g}$ of agar, and $500 \mathrm{ml}$ of distilled water) at $16^{\circ} \mathrm{C}$. Spore suspensions of $1 \times 10^{6}$ spores and mycelium $/ \mathrm{ml}$ were prepared as previously described (17) immediately prior to inoculation.

Seed for each soybean cultivar and PI were obtained through the United States Department of Agriculture (USDA) Soybean Germplasm Collection via the National Genetic Resources Program (NGRP) and the Germplasm Resources Information Network (GRIN) with the exception of cv. Pioneer 9234, which was obtained from Pioneer Hi-Breed International, Inc., Johnston, IA. Seed were germinated in medium-grade vermiculite and approximately 10 to 14 days later, at the VC-V1 growth stage (unifoliate leaves fully expanded), seedlings were inoculated by a modified root dip method (29) as previously described (17). Immediately follow- ing inoculation, the nine seedlings were transplanted to $15.24-\mathrm{cm}$-diameter plastic pots containing a 1:1 mixture of steampasteurized soil (1:1 field soil and sand) and Scott's Metro Mix (The Scott's Company, Marysville, $\mathrm{OH}$ ). Each cultivar or PI was replicated three times with three plants per pot. Pots were arranged in a completely randomized blocked design. Plants were fertilized weekly with Peter's 20-2020 (The Scott's Company) at the recommended rate of $2.4 \mathrm{~g} /$ liter beginning 1 week after inoculation. Plants were grown until the R2 growth stage (full flowering), approximately 7 to 8 weeks depending on the physiological development of each genotype. At R2, each plant per pot was rated for BSR symptom severity by visually estimating the percentage of symptomatic foliar tissue and percentage of internal stem tissue showing browning of the vascular and pith tissues when split longitudinally, and assigning a Horsfall-Baratt (HB) rating (16). Ratings were converted to percentages for analysis using conversion tables from Elanco Products (Division of Eli Lilly, Indianapolis, IN). Disease ratings for the three plants per pot were

Table 1. Characteristics of soybean germ plasm selected for field and greenhouse experiments

\begin{tabular}{|c|c|c|c|c|c|c|}
\hline PI no. ${ }^{a}$ & Designation & $\mathbf{M G}^{\mathbf{b}}$ & Parentage & SCN reaction ${ }^{c}$ & SCN R source & BSR R genes ${ }^{\mathrm{e}}$ \\
\hline $438503 \mathrm{~A}$ & Wu Dow ${ }^{f}$ & II & Unknown & $\mathrm{R}$ & Original & $\ldots$ \\
\hline 548402 & Peking $\mathrm{f}$ & IV & Selected from PI 17852 & $\mathrm{R}$ & Original & $\ldots$ \\
\hline 543855 & Newton ${ }^{\mathrm{f}}$ & II & BSR $101 \times \mathrm{CN} 210$ & $\mathrm{R}$ & Peking & $\ldots$ \\
\hline$\ldots$ & Pioneer $9234^{\mathrm{f}, \mathrm{g}}$ & II & Not available & $\mathrm{R}$ & Peking & $\ldots$ \\
\hline 88788 & No. $5913^{\mathrm{f}}$ & III & Unknown & $\mathrm{R}$ & Original & $\ldots$ \\
\hline 518674 & Fayette $\mathrm{f}_{\mathrm{f} g}$ & III & Williams $\times$ PI 88788 & $\mathrm{R}$ & 88788 & $\ldots$ \\
\hline 592389 & Freeborn ${ }^{\mathrm{f}, \mathrm{g}}$ & I & Ozzie $\times$ Fayette & $\mathrm{R}$ & 88788 & $\ldots$ \\
\hline 540556 & $\mathrm{Jack}^{\mathrm{f}, \mathrm{g}}$ & II-III & Fayette $\times$ Hardin & $\mathrm{R}$ & 88788 & $\ldots$ \\
\hline 540554 & Bell $^{f}$ & I & Fayette $\times$ LN80-10398 & $\mathrm{R}$ & 88788 & $\ldots$ \\
\hline 597386 & Dwight $^{\mathrm{f}, \mathrm{g}}$ & II-III & Jack $\times$ A86-303014 & $\mathrm{R}$ & 88788 & $\ldots$ \\
\hline$\ldots$ & IA $2036^{\mathrm{g}}$ & II & Jack $\times$ A86-301024 & $\mathrm{R}$ & 88788 & $\ldots$ \\
\hline 209332 & No. $4^{\mathrm{f}}$ & IV & Unknown & $\mathrm{R}$ & Original & $\ldots$ \\
\hline 574532 & LN89-5699 f,g & III & Williams $82 \times$ PI 209332 & $\mathrm{R}$ & 209332 & $\ldots$ \\
\hline 583364 & Faribault, $\mathrm{fg}$ & I & M75-2 × L77-906 & $\mathrm{R}$ & 209332 & $\ldots$ \\
\hline 437654 & Er-hei-jan ${ }^{\mathrm{f}}$ & III & Unknown & $\mathrm{R}$ & Original & $\ldots$ \\
\hline 543795 & Hartwigf & $\mathrm{V}$ & Forrest $\times$ PI 437654 & $\mathrm{R}$ & 437654 & $\ldots$ \\
\hline 548316 & Cloud $^{\mathrm{f}}$ & III & Selected from PI 16790 & $\mathrm{R}$ & Original & $\cdots$ \\
\hline 574541 & LN89-5612 ${ }^{\mathrm{f}}$ & III & Williams $82 \times$ Cloud & $\mathrm{R}$ & Cloud & $\ldots$ \\
\hline 89772 & No. $7193^{\mathrm{f}}$ & IV & Unknown & $\mathrm{R}$ & Original & $\ldots$ \\
\hline 574542 & LN89-5717f & IV & Williams $82 \times$ PI 89772 & $\mathrm{R}$ & 89772 & $\ldots$ \\
\hline 404166 & Krasnoarmejskaja $^{\mathrm{f}}$ & III & Unknown & $\mathrm{R}$ & Original & $\ldots$ \\
\hline 92720 & No. $7915^{\mathrm{f}}$ & III & Unknown & $\mathrm{R}$ & Original & $\ldots$ \\
\hline 548317 & Columbia $^{\mathrm{f}}$ & III & Selected from PI 22897 & $\mathrm{R}$ & Original & $\cdots$ \\
\hline 548631 & Williams $\mathrm{g}$ & III & Wayne $\times$ L57-0034 & $\mathrm{S}$ & $\ldots$ & $\ldots$ \\
\hline 518671 & Williams $82^{\mathrm{f}, \mathrm{g}}$ & III & Williams $\times$ Kingwa & S & $\ldots$ & $\ldots$ \\
\hline$\ldots$ & $\mathrm{L} 78-4094^{\mathrm{f}, \mathrm{g}}$ & $\ldots$ & Beeson $\times($ Clark $\times$ PI 84946-2 $)$ & $\mathrm{S}$ & $\ldots$ & Rbs 1 \\
\hline 437833 & Curo Sengocu $\mathrm{f}^{\mathrm{f} g}$ & I & Unknown & $\mathrm{S}$ & $\ldots$ & Rbs 2 \\
\hline 596412 & LN92-12033, f,g & II & Century $84 \times$ PI 437833 & MR & $\ldots$ & Rbs 2 \\
\hline $437970^{\mathrm{f}, \mathrm{g}}$ & & II & Unknown & $\mathrm{S}$ & $\ldots$ & Rbs 3 \\
\hline 548519 & BSR $101^{\mathrm{f}, \mathrm{g}}$ & I & L69040-1604 × A76-304020 & $\mathrm{S}$ & $\ldots$ & Rbs 1,3 \\
\hline 546487 & Archer ${ }^{\mathrm{g}}$ & I & Williams, PRX 54-54, BSR 101 & $\mathrm{~S}$ & $\ldots$ & Rbs 1,3 \\
\hline $567323 \mathrm{~A}^{\mathrm{f}, \mathrm{g}}$ & $\ldots$ & II & Unknown & $\mathrm{S}$ & $\ldots$ & $\ldots$ \\
\hline 518669 & Corsoy $79^{\mathrm{g}}$ & II & Corsoy $\times$ Lee 68 & $\mathrm{~S}$ & $\ldots$ & $\ldots$ \\
\hline 548529 & Century $84^{\circ}$ & II & Century $\times$ Williams 82 & $\mathrm{~S}$ & $\ldots$ & $\ldots$ \\
\hline 542768 & Sturdy $\mathrm{f}, \mathrm{g}$ & I & M70-127 × Century & S & $\ldots$ & $\cdots$ \\
\hline
\end{tabular}

${ }^{\text {a }}$ Plant introduction or accession number.

${ }^{\mathrm{b}} \mathrm{MG}=$ maturity group.

${ }^{\mathrm{c}}$ Reaction of soybean germ plasm to the soybean cyst nematode $(\mathrm{SCN}) ; \mathrm{R}=$ resistant, $\mathrm{MR}=$ moderately resistant; $\mathrm{S}=$ susceptible.

${ }^{\mathrm{d}}$ Soybean germ plasm used to attain resistance to the soybean cyst nematode.

${ }^{\mathrm{e}}$ Gene or genes designated for resistance to the disease brown stem rot (BSR).

${ }^{\mathrm{f}}$ Soybean germ plasm used in greenhouse experiments.

$\mathrm{g}$ Soybean germ plasm used in field experiments. 
averaged and the means analyzed in a oneway analysis of variance (ANOVA) with a Fisher's least significant difference (LSD) comparison of all soybean genotypes using the PROC GLM procedure of the SAS statistical analytical software system (SAS Institute, Cary, NC). Comparison of BSR foliar and internal stem symptom severity across experiments was analyzed with a Spearmen's rank correlation coefficient (Rho) using the PROC CORR SPEARMAN procedure of SAS. Statistical significant for all tests were determined at the $5 \%$ level of probability $(P=0.05)$. Reaction to BSR development for each soybean genotype (resistant or susceptible) was determined based on the level of BSR symptom severity observed for BSRresistant and -susceptible checks.

Field experiments. Eight SCN-resistant cultivars were selected based on the results of greenhouse experiments, parentage, and maturity groups conducive to Wisconsin. SCN- and BSR-resistant and -susceptible genotypes were included as checks (Table 1). Experiments were conducted at two locations maintained by the University of Wisconsin: the Hancock Agricultural Research Station, Hancock, WI and the West
Madison Agricultural Research Station, Madison, WI. The field site at Hancock was composed of a Plainfield sandy loam soil (Mesic Typic Udipsamment, pH 6.3) and naturally infested with SCN (average population at planting $=3,167$ eggs $/ 100$ $\mathrm{cm}^{3}$ of soil) and $P$. gregata. The field site was prepared using a moldboard plow and Dyna-drive and, prior to planting, received a one-time application of 0-0-60 fertilizer at $280 \mathrm{~kg} / \mathrm{ha}$. Applications of Lasso EC (4.7 liter/ha; Monsanto, St. Louis), Linex 4L (0.6 kg/ha; Griffin, Valdosta, GA), and Ultra Blazer 2S (0.6 liter/ha; BASF, Mount Olive, NJ) were applied for weed control. The West Madison field location was composed of Plano silt loam soil (Mesic Typic Argiudoll, $\mathrm{pH}$ 6.3) and naturally infested with $P$. gregata. The field site was chisel tilled in the fall of 1999 and finished using a soil finisher in the spring of 2000. Herbicides Prowl 3.3 EC (3.5 liter/ha; BASF, Mount Olive, NJ) and Sencor 75 DF (0.6 kg/ha; Bayer, Pittsburgh, PA), were applied prior to planting.

Seed for each soybean genotype was obtained from 1999 seed increases (seed originally obtained through the USDA Soybean Germplasm Collection via NGRP and GRIN) with the exception of cvs. Pioneer 9234 and IA 2036, which were obtained from Pioneer Hi-Bred Inc., Johnston, IA and the Iowa Crop Improvement Association, Ames, IA, respectively. Plots for each soybean genotype at both locations were composed of four 6-m rows (two outer border rows and two inner test rows) spaced $0.8 \mathrm{~m}$ apart and arranged in a randomized complete block design with four replications. Plots were planted 9 May 2000 (Hancock) and 2 May 2000 (West Madison) at a rate of 30 seeds $/ \mathrm{m}$ of row using a John Deere (Moline, IL) flex planter.

Plots were rated for BSR symptom severity by visually estimating the percentage of symptomatic foliar tissue in the testrow canopy four times, on 18 July, $11 \mathrm{Au}-$ gust, 29 August, and 7 September for Hancock and 12 July, 11 August, 22 August, and 4 September for West Madison, and assigning an HB rating. Dates for each canopy foliar rating corresponded approximately to R2-R3 (full flowering and early pod development), R4-R5 (late pod development and early pod fill), R5-R6 (pod fill), and R6-R7 (late pod fill and beginning maturity). Ratings were converted to

Table 2. Percent foliar and internal stem tissue symptomatic of brown stem rot (BSR) for 30 soybean genotypes challenged with a genotype A isolate of Phialophora gregata in two greenhouse experiments

\begin{tabular}{|c|c|c|c|c|c|c|}
\hline \multirow[b]{3}{*}{ Genotype } & \multirow[b]{3}{*}{ SCN R source ${ }^{b}$} & \multirow[b]{3}{*}{ BSR R genes ${ }^{c}$} & \multicolumn{4}{|c|}{ Symptom severity ${ }^{\mathrm{a}}$} \\
\hline & & & \multicolumn{2}{|c|}{ Experiment 1} & \multicolumn{2}{|c|}{ Experiment 2} \\
\hline & & & Foliar & Stem & Foliar & Stem \\
\hline Wu Dow & Original & $\ldots$ & 64 & 60 & 95 & 60 \\
\hline Peking & Original & $\ldots$ & 86 & 5 & 1 & 5 \\
\hline Newton & Peking & $\ldots$ & 41 & 40 & 70 & 40 \\
\hline Pioneer 9234 & Peking & $\ldots$ & 17 & 69 & 3 & 22 \\
\hline PI 88788 & Original & $\ldots$ & 91 & 8 & 28 & 13 \\
\hline Fayette & 88788 & $\ldots$ & 2 & 4 & 0 & 2 \\
\hline Bell & 88788 & $\ldots$ & 6 & 14 & 0 & 2 \\
\hline Jack & 88788 & $\ldots$ & 4 & 8 & 0 & 2 \\
\hline Freeborn & 88788 & $\ldots$ & 1 & 3 & 0 & 2 \\
\hline Dwight & 88788 & $\ldots$ & 64 & 59 & 0 & 31 \\
\hline PI 209332 & Original & $\ldots$ & 15 & 2 & 0 & 3 \\
\hline LN89-5699 & 209332 & $\ldots$ & 60 & 2 & 0 & 2 \\
\hline Faribault & 209332 & $\ldots$ & 35 & 9 & 0 & 4 \\
\hline PI 437654 & Original & $\ldots$ & 89 & 15 & 98 & 65 \\
\hline Hartwig & 437654 & $\ldots$ & 56 & 40 & 2 & 5 \\
\hline Cloud & Original & $\ldots$ & 66 & 37 & 91 & 13 \\
\hline LN89-5612 & Cloud & $\ldots$ & 54 & 27 & 49 & 26 \\
\hline PI 89772 & Original & $\ldots$ & 46 & 64 & 31 & 19 \\
\hline LN89-5717 & 89772 & $\ldots$ & 2 & 6 & 0 & 2 \\
\hline PI 404166 & Original & $\ldots$ & 76 & 38 & 13 & 5 \\
\hline PI 92720 & Original & $\ldots$ & 76 & 22 & 84 & 75 \\
\hline Columbia & Original & $\ldots$ & 75 & 30 & 33 & 8 \\
\hline \multicolumn{7}{|c|}{ BSR-resistant checks } \\
\hline LN92-12033 & $\ldots$ & $R b s 2$ & 2 & 15 & 0 & 1 \\
\hline L78-4094 & $\ldots$ & $R b s 1$ & 10 & 9 & 57 & 13 \\
\hline PI 437833 & $\ldots$ & $R b s 2$ & 5 & 17 & 0 & 2 \\
\hline PI 437970 & $\ldots$ & Rbs 3 & 2 & 3 & 0 & 0 \\
\hline BSR 101 & $\ldots$ & Rbs 1,3 & 11 & 30 & 8 & 19 \\
\hline PI 567323A & $\ldots$ & $\ldots$ & 1 & 11 & 0 & 2 \\
\hline \multicolumn{7}{|c|}{ BSR/SCN-susceptible checks } \\
\hline Williams 82 & $\ldots$ & $\ldots$ & 40 & 40 & 39 & 37 \\
\hline Sturdy & $\ldots$ & $\ldots$ & 20 & 78 & 13 & 40 \\
\hline $\operatorname{LSD}^{\mathrm{d}}$ & $\ldots$ & $\ldots$ & 42 & 37 & 34 & 25 \\
\hline
\end{tabular}

${ }^{\text {a }}$ Percent tissue symptomatic of BSR averaged for three replications.

${ }^{\mathrm{b}}$ Soybean germ plasm used to attain resistance to the soybean cyst nematode (SCN).

${ }^{\mathrm{c}}$ Gene or genes designated for resistance to BSR.

${ }^{\mathrm{d}} \mathrm{LSD}=$ Fisher's least significant difference $(P=0.05)$. 
percentages as previously described for greenhouse experiments and area under the disease progress curves (AUDPCs) were calculated as previously described (23). At R7 (beginning maturity), five plants were arbitrarily selected from within the two test rows and rated individually for BSR symptom severity of foliar and internal stem tissue as previously described for greenhouse experiments. Percentage of internal root tissue symptomatic of BSR also was assessed by longitudinally splitting 7 to 10 $\mathrm{cm}$ of the taproot immediately below the root-stem interface. Disease ratings were converted to percentages and each of the five plants per plot were averaged to calculate a plot mean.

At R8 (full maturity), a 5.2-m length of the two test rows, per plot, was harvested on 19 October (Hancock) and 16 October (West Madison) using an Almaco (Nevada, IA) plot combine and evaluated for yield, percent moisture content, height, and lodging. Disease ratings and agronomic data for Hancock and West Madison field locations were analyzed in a one-way ANOVA, with an LSD comparison of means. Rho was calculated to compare the level of BSR symptom severity observed within and across the two field locations. All statistical analyses were conducted as previously described for greenhouse experiments.

\section{RESULTS}

Greenhouse experiments. Of the 10 sources of SCN resistance evaluated in this study, only PI 209332 consistently expressed resistance to BSR symptom development similar to standard BSR-resistant checks (Table 2). The nine remaining sources of SCN resistance, with the exception of Peking, which expressed differing levels of BSR symptom development between the two greenhouse experiments, consistently expressed levels of BSR symptom severity exceeding those levels observed for BSR-susceptible checks (Table 2). As previously observed (18), soybean breeding line LN89-5717, derived from SCN-resistant PI 89772, and cvs. Jack, Bell, Freeborn, and Fayette, all derived from SCN-resistant PI 88788, expressed resistance to BSR development, similar to BSR-resistant checks, in both greenhouse experiments, while those culti- vars derived from SCN-resistant PI 209332, Cloud, and Peking, did not (Table 2). Dwight, a cultivar also derived from PI 88788, expressed susceptibility to BSR development, based on both foliar and internal stem symptom severity, for the first greenhouse experiment and susceptibility based on only the internal stem symptoms in the second experiment (Table 2).

BSR foliar and internal stem symptom severity for the 30 soybean genotypes evaluated were significantly correlated (Table 3) across the two greenhouse experiments despite the suppressive impact of higher temperatures on disease development, which were observed in greenhouse experiment 2 . The two methods utilized in these experiments to evaluate resistant and susceptible soybean genotypes (foliar and internal stem symptoms) were inconsistently correlated across the two greenhouse experiments (Table 3). In greenhouse experiment 1 , resistant and susceptible genotypes assessed using BSR foliar symptom development were not significantly correlated to resistant and susceptible genotypes assessed using BSR internal symptom development (Table 3). In contrast, the reaction of soybean genotypes to BSR development was significantly correlated for foliar and internal stem symptoms in greenhouse experiment 2 (Table 3 ). Though development of internal stem symptoms appears to be less effected by environmental changes than foliar symptom development, segregation of resistant and susceptible genotypes was considerably less efficient than segregation based on foliar symptom development (Table 2). Soybean breeding line LN89-5699 and cv. Faribault, assessed as resistant based on internal stem symptom severity for both greenhouse experiments, were highly susceptible based on BSR foliar symptoms when temperatures favored BSR development. Though temperatures less than $27^{\circ} \mathrm{C}$ are reported to favor BSR development $(1,12)$, SCN-resistant PI 437654, Newton, PI 92720, Wu Dow, and Cloud showed higher BSR foliar symptom development under increased air temperatures (Table 2).

Field experiments. At the Hancock field location, all cultivars with SCN resistance expressed BSR foliar symptom severity similar to BSR-resistant checks (Fig.
1). Furthermore, SCN-susceptible checks Williams and Williams 82 also expressed minimal foliar symptom severity. BSR internal stem and internal root symptom development for cultivars derived from SCN-resistant PI 209332 and Peking, as well as for standard BSR-resistant checks, generally exceeded that observed for all SCN-resistant PI 88788-derived cultivars (Fig. 1).

At the West Madison field location, cultivars derived from SCN-resistant PI 88788 , with the exception of Freeborn, expressed lower BSR foliar symptom development than BSR-resistant checks (Fig. 2). However, the level of BSR foliar symptoms observed for Freeborn (maturity group I) may be the result of confusing early maturity with BSR symptom development. This conclusion is supported by the absence of foliar symptoms for Freeborn until the final $\mathrm{R} 7$ rating and the absence of variation in disease severity across four replicate plots. Resistance to BSR internal stem and internal root symptom development for all PI 88788-derived cultivars generally exceeded that observed for BSR-resistant checks. As observed at the Hancock field location, SCN-susceptible checks Williams and Williams 82 expressed minimal BSR foliar symptom development (Figs. 1 and 2). Cultivars derived from SCN-resistant PI 209332 and Peking expressed BSR foliar, internal stem, and internal root symptom severity similar to BSR-susceptible checks (Fig. 2). BSR foliar and internal stem symptom severity for the 20 soybean genotypes evaluated were significantly correlated across the two field locations (Table 4). Furthermore, the evaluation of resistant and susceptible soybean genotypes, based on either BSR foliar or internal stem symptom development, also was significantly correlated for both Hancock and West Madison (Table 4).

BSR development, as determined by AUDPC, which negatively correlates with yield (Hancock: Rho $=-0.54, P=0.015$; West Madison: Rho $=-0.19, P=0.411$ ), was consistently lower than standard BSRresistant checks for PI 88788-derived cultivars at both field locations (Table 5). At West Madison, AUDPC for cultivars derived from PI 209332 and Peking were similar to BSR-resistant checks yet were

Table 3. Spearman's Rank Correlation Coefficient (Rho) for brown stem rot foliar and internal stem symptom severity of 30 soybean genotypes evaluated in two greenhouse experiments

\begin{tabular}{|c|c|c|c|c|c|c|c|c|}
\hline \multirow[b]{3}{*}{ Experiment } & \multicolumn{4}{|c|}{ Experiment 1} & \multicolumn{4}{|c|}{ Experiment 2} \\
\hline & \multicolumn{2}{|c|}{ Foliar } & \multicolumn{2}{|c|}{ Stem } & \multicolumn{2}{|c|}{ Foliar } & \multicolumn{2}{|c|}{ Stem } \\
\hline & Rho & $P>F$ & Rho & $P>F$ & Rho & $P>F$ & Rho & $P>F$ \\
\hline \multicolumn{9}{|l|}{ Experiment 1} \\
\hline Foliar & 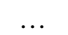 & 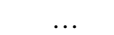 & 0.34 & 0.0686 & 0.64 & 0.0001 & 0.66 & $<0.0001$ \\
\hline Stem & 0.34 & 0.0686 & $\ldots$ & $\ldots$ & 0.55 & 0.0018 & 0.66 & $<0.0001$ \\
\hline \multicolumn{9}{|l|}{ Experiment 2} \\
\hline Foliar & 0.64 & 0.0001 & 0.55 & 0.0018 & & & 0.82 & $<0.0001$ \\
\hline Stem & 0.66 & $<0.0001$ & 0.66 & $<0.0001$ & 0.82 & $<0.0001$ & $\ldots$ & $\ldots$ \\
\hline
\end{tabular}


generally higher than BSR-resistant checks at the Hancock field location. Overall, AUDPC for cultivars derived from PI 209332 and Peking exceeded those obtained for PI 88788-derived cultivars. Furthermore, yields obtained for PI 88788derived cultivars were, in general, higher than yields obtained for PI 209332 and Peking-derived cultivars and for BSRresistant checks at both field locations (Table 5).

\section{DISCUSSION}

Previous studies $(4,5,26)$ screening soybean germ plasm for resistance to BSR development have identified sources of resistance equal to current BSR-resistant standards. From the results of this current study, cultivars derived from SCN-resistant PI 88788 have been identified that express resistance to BSR development, across multiple environments, which surpass the resistance of several BSR-resistant standards. The identification of new sources of BSR resistance is necessary to expand the current genetic base of resistant germ plasm, which has relied mostly on PI 84946-2 (Rbs 1 and $R b s$ 3), PI 437833 (Rbs 2), and PI 437970 (Rbs 3) (12,26). The importance of diversifying the current genetic background is emphasized by instances where resistance has been over- come $(4,8,26,37)$ and the instances of BSR susceptibility observed in this study for BSR-resistant genotypes containing the Rbs 1 or Rbs 3 genes. Moreover, surveys conducted to assess the geographical distribution of genotypes A and B of P. gregata throughout the midwestern United States $(9,22)$ have provided data suggesting that genotype A preferentially infects soybean genotypes susceptible to BSR development, while soybean genotypes resistant to BSR development are preferentially infected by the B genotype. Preliminary results obtained from the genotyping of $P$. gregata from the soybean stems collected at Hancock and West Madison indi-
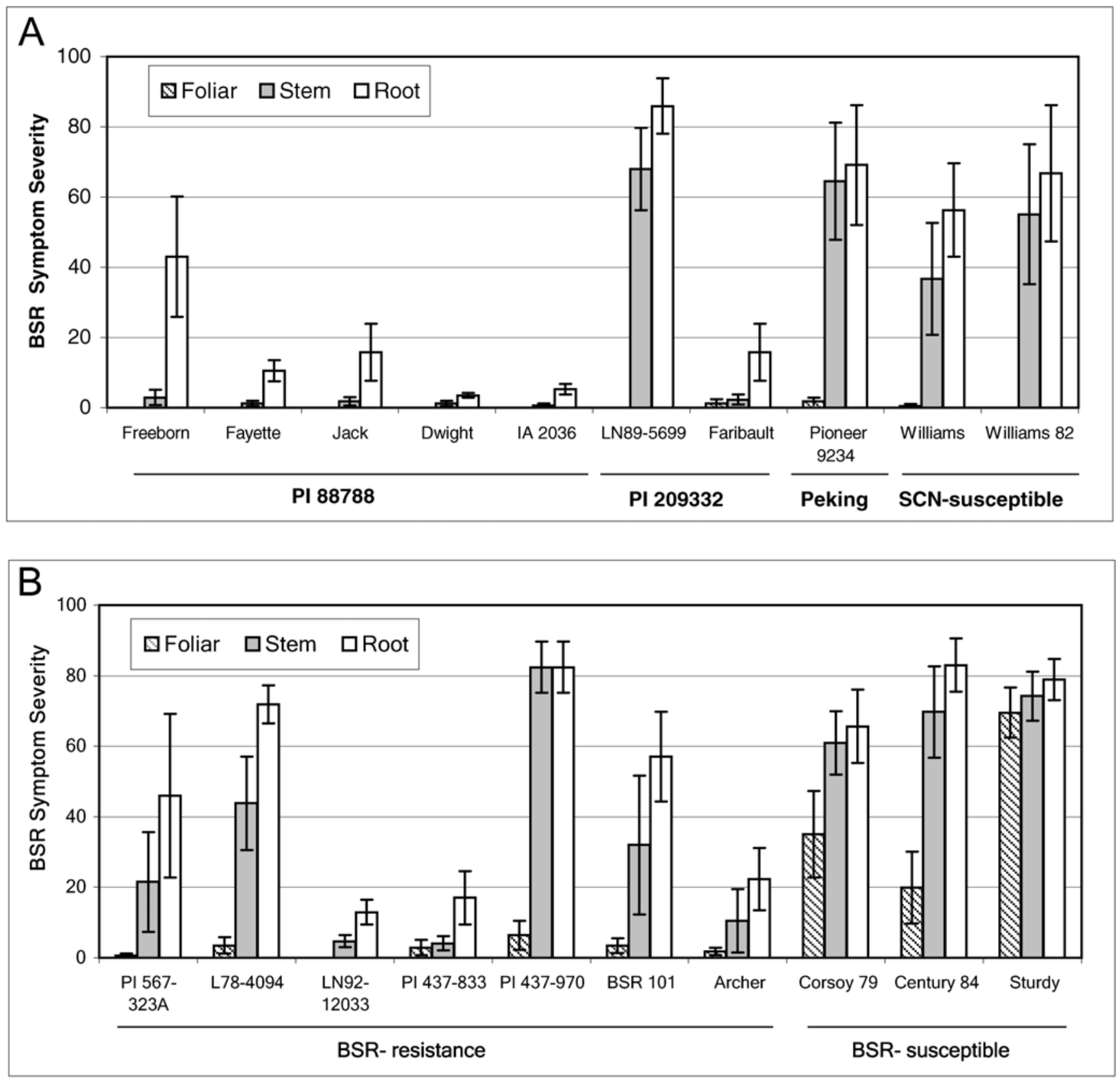

Fig. 1. Percent foliar, internal stem, and internal root tissue symptomatic of brown stem rot (BSR) for 20 soybean genotypes planted in a field naturally infested with Phialophora gregata f. sp. sojae and the soybean cyst nematode (SCN) at Hancock, WI. A, Comparison of soybean genotypes with resistance to SCN derived from three sources of SCN resistance (PI = plant introductions) and two SCN-susceptible checks. B, Comparison of soybean genotypes resistant and susceptible to BSR development. Bars represent standard error of the mean. Fishers least significant difference values $(P=0.05)$ : foliar $=12.0$; stem $=30.0 ;$ root $=31.0$. 
cate that BSR-resistant BSR 101, Archer, PI 437970, and L78-4094 are infected preferentially by the more virulent (17) A genotype of $P$. gregata (data not shown). Similar results also were reported by Chen et al. (9) for cvs. BSR 101, Archer, and L78-4094.

Results of both greenhouse and field experiments have identified resistance to BSR development in cultivars derived from SCN-resistant PI 88788. However, PI 88788, which was susceptible to BSR development under greenhouse conditions, does not appear to be the sole source of resistance observed for PI 88788-derived cultivars. Breeding line LN89-5717, de- rived from SCN-resistant PI 89772, also consistently showed resistance to BSR development under greenhouse conditions; yet, like cultivars derived from PI 88788 , resistance to BSR development observed for LN89-5717 does not appear to be conferred by PI 89772.

Recently, Bachman and Nickell (3) proposed a new model for BSR resistance. From their study, they hypothesized that two or more genes, located on independently segregating loci, condition resistance to BSR. Their model proposed that BSRresistant genes $R b s$ 1, Rbs 2, and Rbs 3, previously identified at different, independently segregating loci, be referred to as "genes necessary for resistance to brown stem rot", or "Nrb" genes, and designated "Nrb 1", "Nrb 2", and "Nrb 3". One or more of the designated $\mathrm{Nrb}$ genes must then interact with another locus or cluster of loci, designated "R", to confer the BSR resistance response. Based on this model, BSRresistant soybean genotype L78-4094, PI 437833, and PI 437970 would be "Nrb1 nrb 2 nrb 3 R"; "nrb 1 Nrb 2 nrb 3 R"; and "nrb 1 nrb 2 Nrb 3 R", respectively.

SCN-susceptible cvs. Williams and Williams 82, which are resistant (17) and moderately susceptible, respectively, to BSR development under greenhouse conditions, expressed BSR foliar symptom
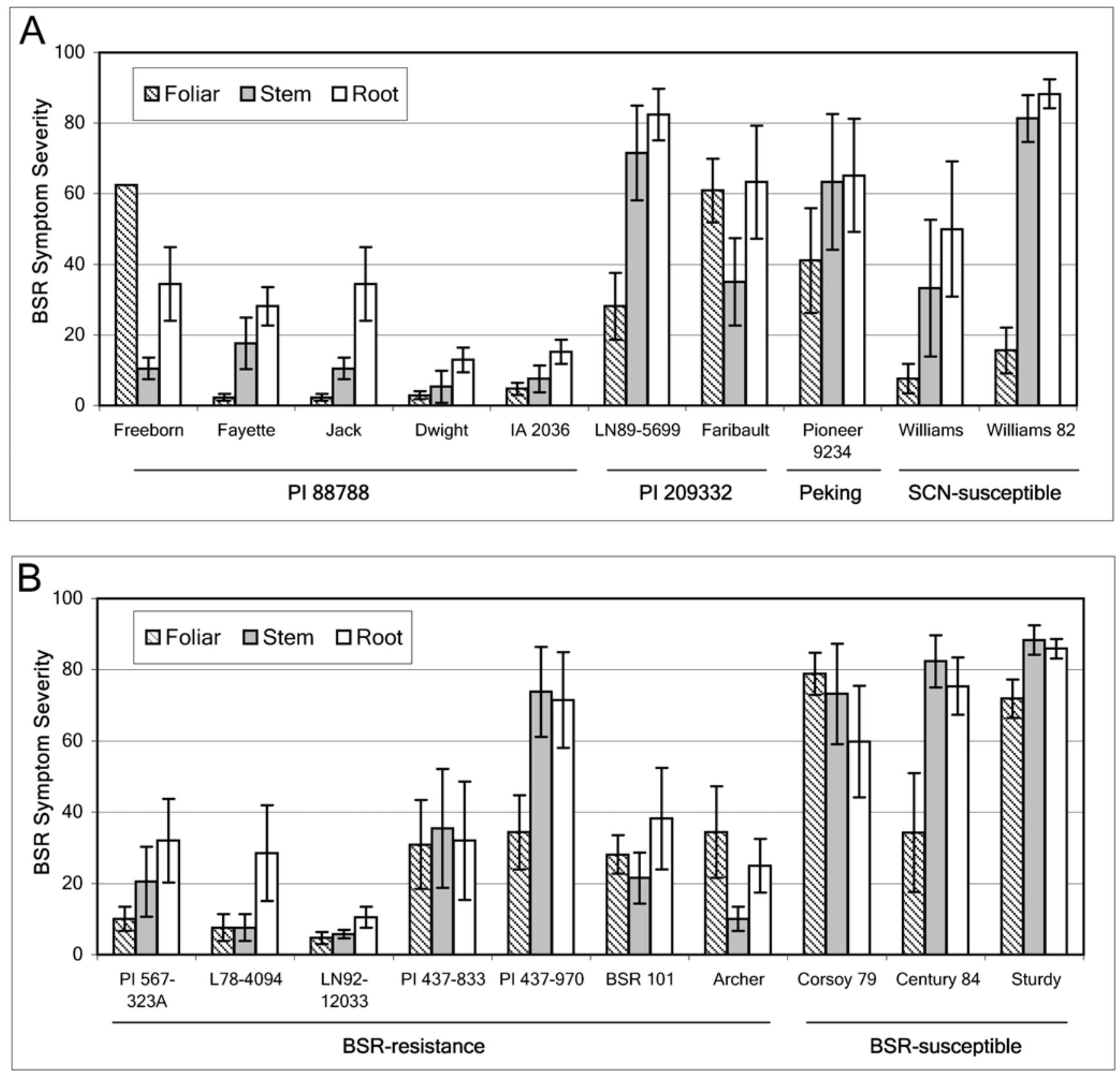

Fig. 2. Percent foliar, internal stem, and internal root tissue symptomatic of brown stem rot (BSR) for 20 soybean genotypes planted in a field naturally infested with Phialophora gregata f. sp. sojae at Madison, WI. A, Comparison of soybean genotypes with resistance to the soybean cyst nematode (SCN) derived from three sources of SCN resistance (PI = plant introductions) and two SCN-susceptible checks. B, Comparison of soybean genotypes resistant and susceptible to BSR development. Bars represent standard error of the mean. Fishers least significant difference values $(P=0.05)$ : foliar $=22.0$; stem $=28.0$; root $=33.0$. 
severity similar to BSR-resistant checks at Hancock and West Madison field locations. All PI 88788-derived cultivars and PI 89772-derived LN89-5717 contain either Williams or Williams 82 in their parentage and may have derived their resistance to BSR development from these cultivars. Moreover, through the use of genetic markers, a region located on soybean linkage group J, tracing to PI 88788, has been identified in PI 88788-derived cultivars. This region has been shown to contain a major BSR-resistant quantitative trait locus in a cross where PI 88788-derived Bell was used as a BSR-resistant parent. (28). Based on the results of the present study, the parentage of PI 88788-derived cultivars and PI 89772-derived LN89-5717, and the BSR resistance model proposed by Bachman and Nickell (3), it is hypothesized that cultivars Williams and Williams 82 contribute the major resistant genes (Nrb gene or genes) and PI 88788, and possibly PI 89772, contribute modifiers ( $R$ genes) necessary for complete expression of resistance to BSR.
Differences in BSR symptom development observed for Williams and Williams 82 may be attributed to the presence of Kingwa in the parentage of Williams 82 . Kingwa, which contains the Rps $1 \mathrm{k}$ gene for resistance to multiple races of Phytophthora sojae Kaufmann \& Gerdermann, is a single plant selection from Peking. Genes obtained from Peking, which was susceptible to BSR development, may interfere with the proposed BSR resistance from Williams in subsequent crosses. A similar explanation may be used to explain the susceptibility to BSR development observed for cultivars derived from SCNresistant PI 209332, which expressed BSR resistance in greenhouse experiments. Cultivars derived from PI 209332, as well as cv. Newton, a cultivar derived from BSR-resistant BSR101 (Table 1), both are examples of BSR-susceptible progeny derived from crosses of BSR-resistant and -susceptible parents.

The differences in BSR symptom development between greenhouse and field environments observed for PI 88788-de- rived Dwight may be attributed to parentage or genotype of $P$. gregata selected for greenhouse experiments. PI 88788-derived cvs. Bell, Freeborn, and Jack all contain Fayette (developed from Williams and PI 88788) as a direct parent. In contrast, Jack was selected as the SCN-resistant parent for Dwight and the corresponding reaction of Dwight to BSR development in greenhouse and field environments may be dependent upon the transfer of both proposed $\mathrm{Nrb}$ genes and R genes from Fayette. Alternatively, resistance to BSR development observed for Dwight under field conditions may be attributed to inoculation occurring "naturally" from a genetically variable population of $P$. gregata $(9,15)$. The preliminary results obtained from the genotyping of $P$. gregata from soybean stems collected at Hancock and West Madison suggest that cvs. Dwight and IA 2036, which shares a similar parentage to Dwight, are either uninfected (pathogen not detected) or preferentially colonized by the less virulent (17) genotype B isolate (data not shown). Malvick et al. (22) re-

Table 4. Spearman's Rank Correlation Coefficient (Rho) for brown stem rot foliar and internal stem symptom severity of 20 soybean genotypes evaluated at two field locations

\begin{tabular}{|c|c|c|c|c|c|c|c|c|}
\hline \multirow[b]{3}{*}{ Location } & \multicolumn{4}{|c|}{ Hancock, WI } & \multicolumn{4}{|c|}{ Madison, WI } \\
\hline & \multicolumn{2}{|c|}{ Foliar } & \multicolumn{2}{|c|}{ Stem } & \multicolumn{2}{|c|}{ Foliar } & \multicolumn{2}{|c|}{ Stem } \\
\hline & Rho & $P>F$ & Rho & $P>F$ & Rho & $P>F$ & Rho & $P>F$ \\
\hline \multicolumn{9}{|l|}{ Hancock } \\
\hline Foliar & $\ldots$ & . & 0.65 & 0.002 & 0.64 & 0.0024 & 0.55 & 0.0124 \\
\hline Stem & 0.65 & 0.002 & $\ldots$ & $\ldots$ & 0.55 & 0.0123 & 0.77 & $<0.0001$ \\
\hline \multicolumn{9}{|l|}{ Madison } \\
\hline Foliar & 0.64 & 0.0024 & 0.55 & 0.0123 & $\ldots$ & & 0.61 & 0.0046 \\
\hline Stem & 0.55 & 0.0124 & 0.77 & $<0.0001$ & 0.61 & 0.0046 & $\ldots$ & $\ldots$ \\
\hline
\end{tabular}

Table 5. Yield and area under the disease progress curve (AUDPC) for 20 soybean genotypes at two field locations

\begin{tabular}{|c|c|c|c|c|c|c|}
\hline \multirow[b]{2}{*}{ Genotype } & \multirow[b]{2}{*}{ SCN R source ${ }^{a}$} & \multirow[b]{2}{*}{ BSR R genes $^{\mathrm{b}}$} & \multicolumn{2}{|c|}{ Hancock, WI } & \multicolumn{2}{|c|}{ Madison, WI } \\
\hline & & & Yield $^{\mathrm{c}}$ & AUDPC & Yield $^{\mathrm{c}}$ & AUDPC \\
\hline Freeborn & 88788 & $\ldots$ & 2.0 & 0 & 3.2 & 36 \\
\hline Fayette & 88788 & $\ldots$ & 2.6 & 0 & 2.8 & 6 \\
\hline Jack & 88788 & $\ldots$ & 3.1 & 0 & 3.2 & 6 \\
\hline Dwight & 88788 & $\ldots$ & 3.2 & 0 & 3.9 & 8 \\
\hline IA 2036 & 88788 & $\ldots$ & 2.4 & 0 & 2.7 & 11 \\
\hline LN89-5699 & 209332 & $\ldots$ & 2.2 & 0 & 2.1 & 23 \\
\hline Faribault & 209332 & $\ldots$ & 2.6 & 2 & 2.4 & 42 \\
\hline Pioneer 9234 & Peking & $\ldots$ & 3.0 & 3 & 2.9 & 30 \\
\hline \multicolumn{7}{|c|}{ BSR-resistant checks } \\
\hline PI 567323A & $\ldots$ & . & 1.7 & 1 & 2.2 & 22 \\
\hline L78-4094 & $\ldots$ & Rbs 1 & 1.3 & 5 & 2.3 & 14 \\
\hline LN92-12033 & $\ldots$ & Rbs 2 & 2.2 & 0 & 2.8 & 11 \\
\hline PI 437833 & $\ldots$ & Rbs 2 & 2.0 & 1 & 1.9 & 28 \\
\hline PI 437970 & $\ldots$ & Rbs 3 & 1.5 & 13 & 2.8 & 29 \\
\hline BSR 101 & $\ldots$ & Rbs 1,3 & 2.0 & 20 & 3.2 & 27 \\
\hline Archer & $\ldots$ & Rbs 1,3 & 1.6 & 5 & 3.0 & 24 \\
\hline \multicolumn{7}{|c|}{ BSR/SCN-susceptible checks } \\
\hline Corsoy 79 & $\ldots$ & $\ldots$ & 1.0 & 33 & 2.3 & 61 \\
\hline Century 84 & $\ldots$ & $\ldots$ & 1.3 & 38 & 2.7 & 33 \\
\hline Sturdy & $\ldots$ & $\ldots$ & 1.5 & 54 & 2.3 & 53 \\
\hline Williams & $\ldots$ & $\ldots$ & 1.2 & 1 & 1.9 & 12 \\
\hline Williams 82 & $\ldots$ & $\ldots$ & 1.2 & 0 & 2.0 & 28 \\
\hline $\mathrm{LSD}^{\mathrm{d}}$ & $\cdots$ & $\cdots$ & 0.5 & 17 & 0.7 & 15 \\
\hline
\end{tabular}

${ }^{a}$ Soybean germ plasm used to attain resistance to the soybean cyst nematode (SCN).

${ }^{\mathrm{b}}$ Gene or genes designated for resistance to the disease brown stem rot (BSR).

${ }^{c}$ Yield in Mg/ha.

${ }^{\mathrm{d}}$ LSD $=$ Fisher's least significant difference $(P=0.05)$. 
ported similar results in a recent survey assessing the geographic distribution of $P$. gregata genotypes throughout the midwestern United States. Therefore, the susceptible reaction of Dwight in greenhouse experiments may be due to the use of a genotype A isolate or the method of inoculation which may have bypassed the propose resistance mechanisms of the root (2).

The SCN is an economically significant pathogen of soybean (40). Distributed throughout the north-central United States (39), the SCN often is found in fields infested with $P$. gregata $(19,21,27,33)$. Recently, extensive controlled environmental studies have identified an increase in BSR symptom severity for soybean cultivars resistant and susceptible to either $P$. gregata or SCN $(33,34)$. As with BSR, control of SCN relies heavily on the use of resistant cultivars with the majority deriving their resistance from PI 88788, Peking, and PI 209332 (10). At the Hancock location, naturally infested with both $P$. gregata and $\mathrm{SCN}$, cultivars derived from SCN-resistant PI 88788 not only expressed resistance to BSR development but also produced a range of yields that exceed that produced by standard BSR-resistant checks. Likewise, the range in yields of PI 88788derived cultivars at West Madison, where the SCN was not present, surpassed the range of yields obtained by standard BSRresistant genotypes. The identification of BSR resistance in PI 88788-derived cultivars, therefore, provides growers and breeders a base of stable, high-yielding germ plasm with resistance to two significant pathogens of soybean.

\section{LITERATURE CITED}

1. Allington, W. B., and Chamberlain, D. W. 1948. Brown stem rot of soybean. Phytopathology 38:793-802.

2. Bachman, M. S., and Nickell, C. D. 1999. Use of reciprocal grafting to study brown stem rot resistance in soybean. Phytopathology 89:5963.

3. Bachman, M. S., and Nickell, C. D. 2000. Investigating the genetic model for brown stem rot resistance in soybean. J. Hered. 91:316321

4. Bachman, M. S., and Nickell, C. D. 2000. High frequency of brown stem rot resistance in soybean germ plasm from central and southern China. Plant Dis. 84:694-699.

5. Bachman, M. S., Nickell, C. D., Stephens, P. A., and Nickell, A. D. 1997. Brown stem rot resistance in soybean germ plasm from central china. Plant Dis. 81:953-956.

6. Bachman, M. S., Nickell, C. D., Stephens, P. A., Nickell, A. D., and Gray, L. E. 1997. The effect of $R b s 2$ on yield of soybean. Crop Sci. 37:1148-1151.

7. Bachman, M. S., Tamulonis, J. P., Nickell, C. D., and Bent, A. F. 2001. Molecular markers linked to brown stem rot resistance genes, $R b s$
1 and $R b s$ 2, in soybean. Crop Sci. 41:527-535.

8. Chen, W., Diers, B. W., and Nelson, R. L. 2001. Phialophora gregata strains pathogenic to resistance allele sources $R b s 1$ and $R b s 3$. (Abstr.) Phytopathology 91:S16.

9. Chen, W., Grau, C. R., Adee, E. A., and Meng, X.-Q. 2000. A molecular marker identifying subspecific population of the soybean brown stem rot pathogen, Phialophora gregata. Phytopathology 90:875-883.

10. Diers, B. W., Skorupska, H. T., Rao-Arelli, A. P., and Cianzio, S. R. 1997. Genetic relationships among soybean plant introductions with resistance to soybean cyst nematodes. Crop Sci. 37:1966-1972.

11. Gray, L. E. 1972. Effect of Cephalosporium gregatum on soybean yield. Plant Dis. Rep. 56:580-581.

12. Gray, L. E., and Grau, C. R. 1999. Brown stem rot. Pages 28-29 in: Compendium of Soybean Diseases. Fourth ed. G. L. Hartman, J. B. Sinclair, and J. C. Rupe, eds. American Phytopathological Society Press, St. Paul, MN.

13. Gray, L. E., and Sinclair, J. B. 1973. The incidence, development, and yield effects of Cephalosporium gregatum on soybeans in Illinois. Plant Dis. Rep. 57:853-854.

14. Hanson, P. M., Nickell, C. D., Gray, L. E., and Sebastian, S. A. 1988. Identification of two dominant genes conditioning brown stem rot resistance in soybean. Crop Sci. 28:41-43.

15. Harrington, T. C., Steimel, J., Workneh, F., and Yang, X. B. 2003. Characterization and distribution of two races of Phialophora gregata in the north-central United States. Phytopathology 93:901-912.

16. Horsfall, J. G., and Barratt, R. W. 1945. An improved grading system for measuring plant disease. (Abstr.) Phytopathology 35:655.

17. Hughes, T. J., Chen, W., and Grau, C. R. 2002. Pathogenic characterization of genotypes A and B of Phialophora gregata f. sp. sojae. Plant Dis. 86:729-735.

18. Kurtzweil, N. C., Hughes, T. J., and Grau, C. R. 1999. Relationship of soybean cyst nematode resistant cultivars to brown stem rot resistance. (Abstr.) Phytopathology 89:S106.

19. Lauer, J. G., Marinka, M. J., Bures, K. A., Gaska, J. M., Grau, C. R., and Kurtzweil, N. C. 2000. Wisconsin soybean variety tests. Univ. Wis. Ext. Bull. A3564.

20. Lewers, K. S., Bronson, C. R., Schupp, J. M., Keim, P., and Shoemaker, R. C. 1999. Detection of linked QTL for soybean brown stem rot resistance in 'BSR 101' as expressed in a growth chamber environment. Mol. Breed. 5:33-42.

21. MacGuidwin, A. E., Grau, C. R., and Oplinger, E. S. 1995. Impact of planting 'Bell', a soybean cultivar resistant to Heterodera glycines, in Wisconsin. J. Nematol. 27:78-85.

22. Malvick, D. K., Chen, W., Kurle, J. E., and Grau, C. R. 2003. Cultivar preference and genotype distribution of the brown stem rot pathogen Phialophora gregata in the midwestern USA. Plant Dis. 87:1250-1254.

23. Mengistu, A., and Grau, C. R. 1987. Seasonal progress of brown stem rot and its impact on soybean productivity. Phytopathology 77: 1521-1529.

24. Mengistu, A., Grau, C. R., and Gritton, E. T. 1986. Comparison of soybean genotypes for resistance to and agronomic performance in the presence of brown stem rot. Plant Dis. 70:1095-1098.
25. Mengistu, A., Tachibana, H., and Grau, C. R. 1991. Selective media for isolation and enumeration of Phialophora gregata from soybean straw and soil. Plant Dis. 75:196-199.

26. Nelson, R. L., Nickell, C. D., Orf, J. H., Tachibana, H., Gritton, E. T., Grau, C. R., and Kennedy, B. W. 1989. Evaluating soybean germ plasm for brown stem rot resistance. Plant Dis. 73:110-114.

27. Oplinger, E. S., Martinka, M. J., Bures, K. A Gaska, J. M., and Grau, C. R. 1999. Wisconsin soybean variety tests. Univ. Wis. Ext. Bull. A3564

28. Patzoldt, M. E., Grau, C. R., Stephens, P. A., Kurtzweil, N. C., Carlson, S. R., and Diers, B. W. Localization of a quantitative trait locus providing brown stem rot resistance in the soybean cultivar Bell. Crop Sci. In press.

29. Sebastian, S. A., Nickell, C. D., and Gray, L. E. 1983. Sequential screening of soybean plants for resistance to Phytophthora rot and brown stem rot. Crop Sci. 23:1214-1215.

30. Sebastian, S. A., Nickell, C. D., and Gray, L. E. 1985. Efficient selection for brown stem rot resistance in soybeans under greenhouse screening conditions. Crop Sci. 25:753-757.

31. Sebastian, S. A., Nickell, C. D., and Gray, L. E. 1986. Relationship between greenhouse and field ratings for brown stem rot reaction in soybean. Crop Sci. 26:665-667.

32. Sills, G. R., Gritton, E. T., and Grau, C. R. 1991. Differential reactions of soybean genotypes to isolates of Phialophora gregata. Plan Dis. 75:687-690.

33. Sugawara, K., Kobayashi, K., and Ogoshi, A. 1997. Influence of the soybean cyst nematode Heterodera glycines) on the incidence of brown stem rot in soybean and adzuki bean. Soil Biol. Biochem. 29:1491-1498.

34. Tabor, G. M., Tylka, G. L., Behm, J. E., and Bronson, C. R. 2003. Heterodera glycines infection increases incidence and severity of brown stem rot in both resistant and susceptible soybean. Plant Dis. 87:655-661.

35. Tachibana, H., Epstein, A. H., and Havlovic, B. J. 1989. Effect of four years of continuous cropping of maturity group II soybeans resistant to brown stem rot on brown stem rot and yield. Plant Dis. 73:846-849.

36. Waller, R. S., Nickell, C. D., and Gray, L. E. 1992. Environmental effects on the development of brown stem rot in soybean. Plant Dis. 76:454-457.

37. Willmot, D. B., and Nickell, C. D. 1989. Genetic analysis of brown stem rot resistance in soybean. Crop Sci. 29:672-674.

38. Willmot, D. B., Nickell, C. D., and Gray, L. E. 1989. Physiologic specialization of Phialo phora gregata on soybean. Plant Dis. 73:290294.

39. Workneh, F., Tylka, G. L., Yang, X. B., Faghihi, J., and Ferris, J. M. 1999. Regiona assessment of soybean brown stem rot, Phy tophthora sojae, and Heterodera glycines using area-frame sampling: Prevalence and effects of tillage. Phytopathology 89:204211.

40. Wrather, J. A., Stienstra, W. C., and Koenning, S. R. 2001. Soybean disease loss estimates for the United States from 1996-1998. Can. J. Plant Pathol. 23:122-131.

41. Young, L. D. 1999. Efficiency gained by screening segregating soybean progenies with soybean cyst nematode race 2 versus race 5 . Crop Sci. 39:1248-1249. 